\title{
Identification of crystals deposited in brain and kidney after xylitol administration by biochemical, histochemical, and electron diffraction methods
}

\author{
G. W. EVANS ${ }^{1}$, GAEL PHILliPS, T. M. MUKHERJEE, M. R. SNOW, \\ J. R. LAWRENCE, AND D. W. THOMAS
}

From the Institute of Medical and Veterinary Science, Frome Road, Adelaide, South Australia, and the Renal Unit, The Queen Elizabeth Hospital, Woodville, South Australia

SYNOPSIS The positive identification of crystals of calcium oxalate occurring in brain and kidney after xylitol administration is described. Biochemical, histochemical, conventional light and electron $c$ microscopical methods, including selected area electron diffraction, were used to characterize the crystals.

The syndrome resulting from intravenous infusion of certain xylitol-containing solutions has been described in detail by Thomas, Edwards, Gilligan, Lawrence, and Edwards (1972a) and by Thomas, Gilligan, Edwards, and Edwards (1972b). The crystals which occurred in the brain and kidney of some of the patients in that series were positively characterized in one case which is described here.

\section{Case Details}

The patient (case 19 from the series of Thomas et al, 1972a) was a male, aged 58 years, who three months before admission had received a renal homotransplant following haemodialysis for chronic renal failure consequent on severe hypertension.

On 24 December 1969 he was admitted to hospital with acute pancreatitis and despite severe hypertension $(210 / 130)$ the BUN at that time was 24 $\mathrm{mg} / 100 \mathrm{ml}$ and the serum creatinine was $1.2 \mathrm{mg} / 100$ $\mathrm{ml}$. The haemoglobin was $12 \cdot 8 \mathrm{~g} / 100 \mathrm{ml}$. The signs of acute pancreatitis resolved during controlled fluid therapy but the patient developed an epigastric mass, thought to be a 'pseudocyst of the pancreas'. In an attempt to improve his general condition he was given xylitol-containing solutions as an intravenous source of calories. Acidosis developed soon after xylitol was administered and subsequently renal

${ }^{1}$ Requests for reprints should be addressed to G.E., Clinical Chemistry Division, Institute of Medical and Veterinary Science, Frome Road, Adelaide, South Australia 5000.

Received for publication 24 October 1972. function deteriorated with rising serum creatinine $(6.9 \mathrm{mg} / 100 \mathrm{ml})$, urea nitrogen $(80 \mathrm{mg} / 100 \mathrm{ml})$, and uric acid $(13 \mathrm{mg} / 100 \mathrm{ml})$ (Fig. 1). At this time the patient also developed 'midbrain' signs, including bilateral sixth nerve paresis, disturbances of conjugate gaze, and nystagmus. A renal biopsy was performed four days after xylitol therapy was begun and in sections rosettes and sheaves of birefringent crystals were seen in the lumen of renal tubules and within tubular cells.

Xylitol infusion had been stopped on the previous

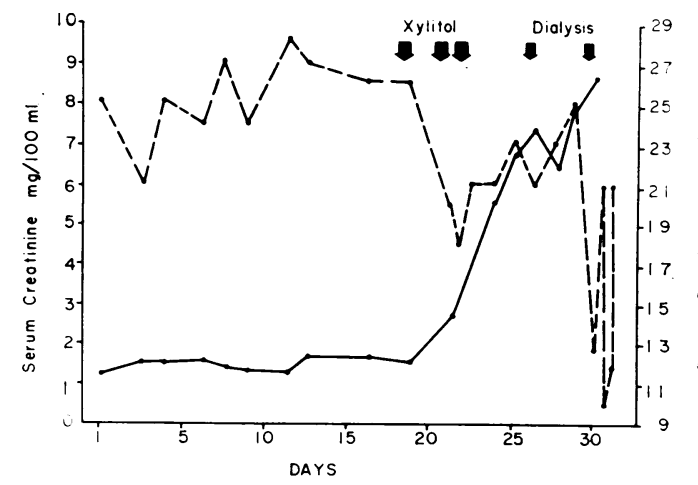

Fig. 1 Graph showing rising serum creatinine (solid line) and falling serum bicarbonate (discontinuous line) following xylitol therapy. Haemodialysis is indicated by smaller arrows. 
day after a total of $1000 \mathrm{ml}$ of $25 \%$ and $500 \mathrm{ml}$ of $50 \%$ solutions had been administered.

Haemodialysis was performed nine days after xylitol was first administered (Fig. 1). During this procedure the patient became shocked, with increasing abdominal pain. Intraabdominal haemorrhage was diagnosed and at laparotomy on the same day a large retroperitoneal haematoma was found behind the pancreas and extending down the left side with no obvious bleeding site. Postoperatively he became disorientated, developed neurological signs, went into respiratory failure and died on the following day.

\section{Materials and Methods}

At necropsy, about 12 hours after death, tissue was removed from the transplanted kidney and midbrain and processed as described below.

Small portions of the solitary kidney, midbrain, and basilar artery were cut into cubes about $1 \mathrm{~mm}$ in diameter under $2.5 \%$ glutaraldehyde in phosphate buffer at $p \mathrm{H} 7 \cdot 3$ and fixed for two hours. The tissue was washed in several changes of the buffer and postfixed for four hours in $2 \%$ osmium tetroxide in the same buffer. Tissue blocks were dehydrated in graded ethanol and embedded in Epon 812 (Luft, 1961). All procedures preceding the $100 \%$ ethanol stage were carried out at $0-4^{\circ} \mathrm{C}$. Thin sections for electron microscopy and electron diffraction were cut on a PorterBlum MT2 ultramicrotome and picked up on uncoated 75/300 mesh copper grids. For conventional electron microscopy sections were stained with either saturated aqueous uranyl acetate or lead citrate (Reynolds, 1963) or both. Some sections were examined unstained, especially those used for selected area electron diffraction. A Hitachi HU 11E electron microscope was used at $75 \mathrm{kV}$, with Ilford N40 photographic plates. The microscope was calibrated for diffraction with potassium chloroplatinate crystals.

Tissue for light microscopy was fixed for three hours in $2.5 \%$ glutaraldehyde in phosphate buffer at $p \mathrm{H} 7 \cdot 3$ or in $10 \%$ buffered formalin. One block of kidney tissue previously fixed in glutaraldehyde was postfixed in formalin for four hours. Tissue fixed only in formalin was embedded according to conventional paraffin-embedding techniques. However, the blocks fixed in glutaraldehyde, with or without postfixation in formalin, were embedded according to the method of Meadows and Schoemaker (1970). Sections stained with haematoxylin and eosin, PAS, von Kossa stain, alizarin red, and methenamine silver were examined by both ordinary light microscopy and with crossed Nicol prisms.

Various solvents, acids, and alkalis were added to unstained sections of kidney under a microscope and the reaction, if any, was observed. The test to identify and demonstrate calcium oxalate in tissue sections, as described by Johnson $(1956,1958)$, was performed.

\section{SILICA-GEL THIN-LAYER AND GAS \\ CHROMATOGRAPHY}

The suspected calcium oxalate crystals isolated from the kidney by the method of James, Seawright, and Steele (1971) were treated with an excess of ethanol and an equal quantity of toluene was then added with a trace of concentrated sulphuric acid. The resulting turbid mixture was refluxed for two minutes and cooled. Aliquots of this were then used for the chromatography steps. Authentic calcium oxalate was treated in the same way.

\section{THIN-LAYER CHROMATOGRAPHY}

The supposed ethyl oxalate derived from the crystals was subjected to thin-layer chromatography using silica gel $G$ (Merck) in the system petroleum ether (bp $60-80^{\circ} \mathrm{C}$ ): ethyl acetate $19: 5$. The compound was visualized using the hydroxylamine-ferric chloride spray reagents described by Whittaker and Wijesundera (1952).

Upon further thin-layer chromatography the section of silica gel corresponding to the $R f$ value of authentic ethyl oxalate (0.58) was scraped off the plate and the compound was eluted. This was subjected to gas-liquid chromatography.

\section{GAS-LIQUID CHROMATOGRAPHY}

The suspected ethyl oxalate specimens were studied by gas chromatography using a Perkin-Elmer model 811 gas chromatograph. The column used (column 1) was a $6 \mathrm{ft}$ glass column containing $0.8 \%$ neopentylglycol adipate on Gas-Chrom Q (Applied Science Laboratories). Chromatography conditions: oven temperature $70^{\circ} \mathrm{C}$, injector temperature $120^{\circ} \mathrm{C}$, detector temperature $125^{\circ} \mathrm{C}$, and carrier flow rate $16 \mathrm{ml} /$ minute. The gas chromatography was repeated using a second column (column 2) packed with a mixture of $0.6 \%$ silicone JXR and $0.6 \%$ cyclohexanedimethanol succinate (Applied Science Laboratories) on Chromosorb W.

\section{Results}

In sections stained with haematoxylin and eosin radially arranged sheaves and rosettes of crystals were seen in the lumen of the renal tubules as well as intracellularly (Fig. 2). These were morphologically the same as crystals seen in the renal biopsy during life. Some of the tubules affected were dilated and the cells atrophic. Scattered foci of lymphocytes 


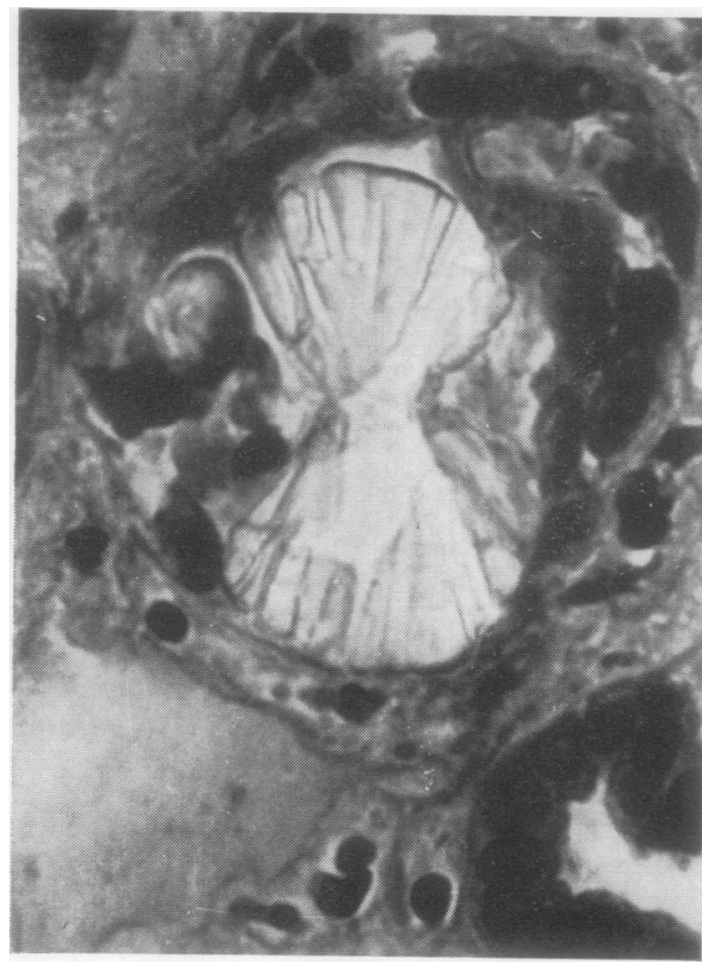

Fig. 2 Light micrograph of renal tubule filled with sheaves of calcium oxalate crystals. Glut/form fixation, $H . \& E$. 832.

were seen. The von Kossa stain for calcium gave a positive black reaction on the crystals. They did not stain with PAS, methenamine silver, or alizarin red. Results of solubility tests (Table I) suggested that the crystals were calcium oxalate. The Johnson test was highly suggestive of the presence of calcium oxalate, because following incineration and the addition of sulphuric acid, bubbles of carbon dioxide were produced. The resulting calcium carbonate stained with alizarin red.

\begin{tabular}{lll}
\hline Solvent & $\begin{array}{l}\text { Renal } \\
\text { Crystals }\end{array}$ & $\begin{array}{l}\text { Calcium } \text { Oxalate } \\
\text { Dihydrate } \text { (Tetragonal } \\
\text { Form of Calcium } \\
\text { Oxalate) }\end{array}$ \\
\hline $\begin{array}{lll}\text { Concentrated and diluted } \mathrm{H}_{2} \mathrm{SO}_{4} & \text { Soluble } \\
\text { Concentrated and diluted } \mathrm{HCl} & \text { Soluble } & \text { Soluble } \\
\text { Glacial acetic acid } & \text { Soluble } \\
\text { 2M acetic acid } & \text { Insoluble } & \text { Insoluble } \\
\text { Saturated } \mathrm{NH}_{4} \mathrm{OH} & \text { Insoluble } & \text { Insoluble } \\
4 \mathrm{M} \mathrm{KOH} & \text { Insoluble } & \text { Insoluble } \\
\text { Insoluble } \\
\text { Chlorotorm }\end{array}$ & $\begin{array}{l}\text { Insoluble } \\
\text { Insoluble }\end{array}$ & $\begin{array}{l}\text { Insoluble } \\
\text { Insoluble }\end{array}$ \\
\hline
\end{tabular}

Table I Solubility tests performed on renal crystals

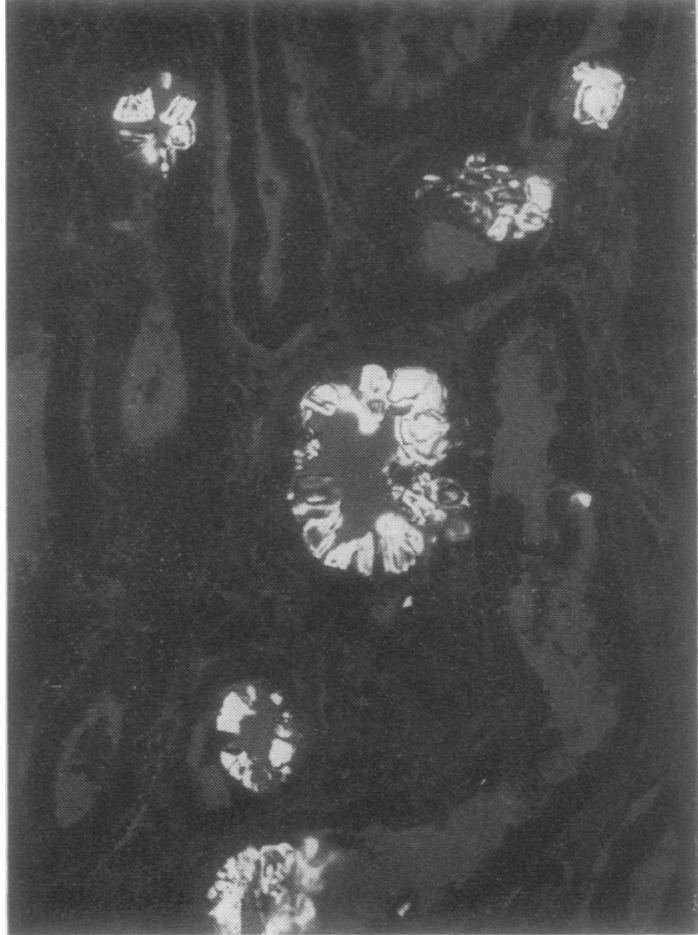

Fig. 3 Light micrograph of kidney using crossed Nicol prisms. Numous birefringent crystals are present in the renal tubules. $H . \& E . \times 246$.

Using crossed Nicol prisms the crystals were found to be strongly birefringent (Fig. 3). Some crystals were also found, by using polarized light in the wall of a midbrain blood vessel. Crystal deposition was not found in other organs.

Electron microscopy was therefore performed on kidney and brain, and although there was considerable postmortem change the cells were still $D$ intact in many areas. Small crystals with lattice planes could be found intracellularly (Fig. 4) as $\mathrm{N}$ well as extracellularly. In Fig. 4 the occurrence of moiré fringes indicates that two flaky crystals are overlapping with their lattice planes at small angles with respect to each other.

Selected area electron diffraction (Fig. 5) on 6 single crystals in brain and kidney gave spot diffraction patterns. The symmetry $(\mathrm{mm})$, systematic absences $(\mathrm{h}+1=2 \mathrm{n}$ for reflections to be present), and axial ratio $(0.585)$ of these patterns are consistent with calcium oxalate dihydrate. The space

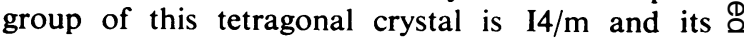
axial ratio is 0.5944 (Donnay, 1963). The less common trihydrate is also tetragonal (space group 


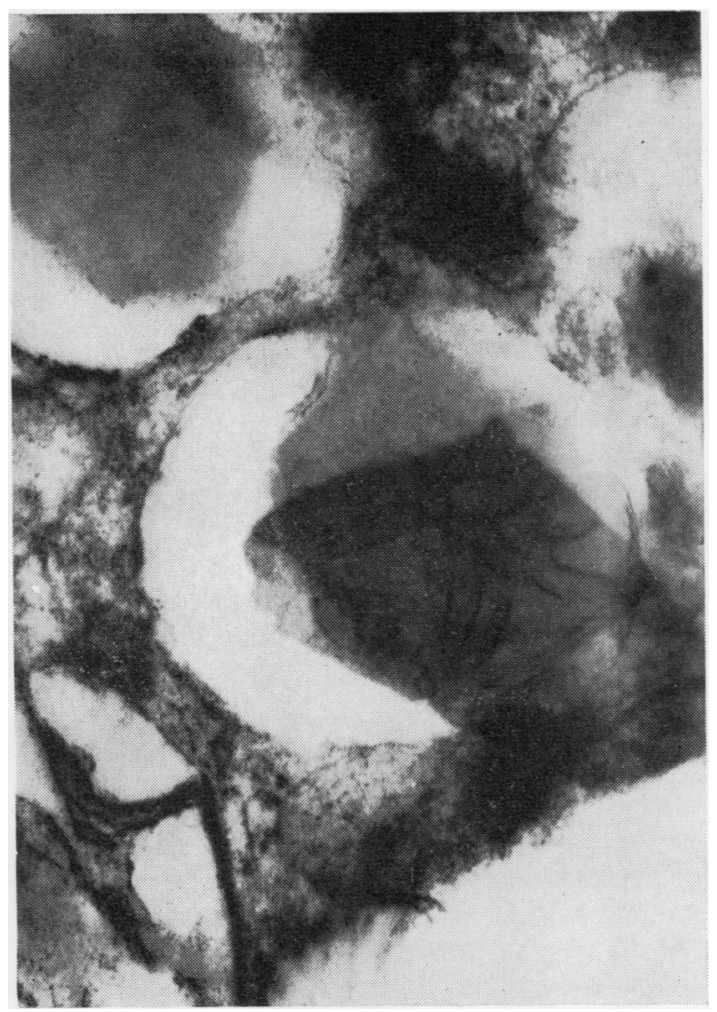

Fig. 4 Flaky crystals within a renal tubular cell vacuole. The occurrence of moiré fringes suggests that two crystals are overlapping with their lattice planes slightly angled with respect to each other. Uranyl acetate/lead citrate $\times 377982$.

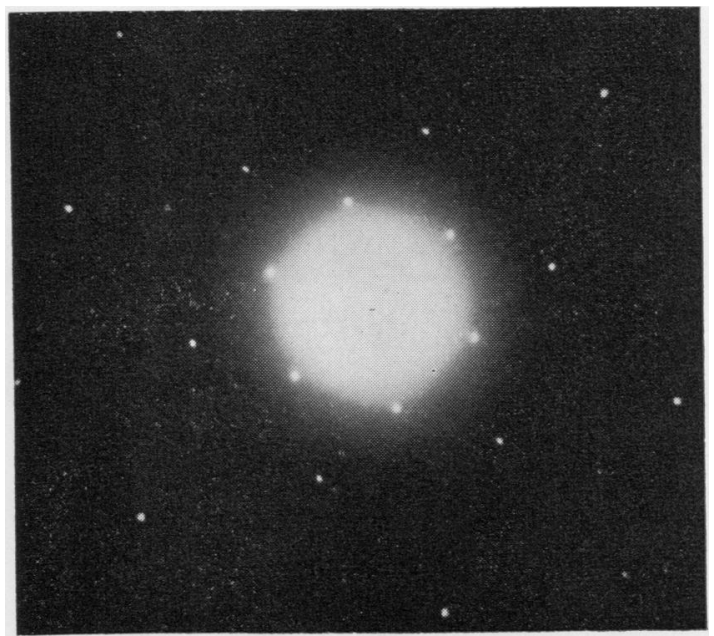

Fig. 5 A typical diffraction pattern obtained from single crystals in kidney or brain. The axial ratio is consistent with that of calcium oxalat dihcydrate. not reported) with a similar axial ratio (0.5961) and cannot be excluded on the basis of these data.

Even though the results of these tests strongly indicated that the crystals deposited in the kidney were calcium oxalate, chromatography provided absolute confirmation. The suspected ethyl oxalate derived from the crystals had an identical $\mathbf{R f}$ value $(0.58)$ to that of authentic ethyl oxalate (BDH) and also the ethyl oxalate prepared from authentic calcium oxalate. On gas chromatography the derivative from the renal crystals had the same retention time $(3.1 \mathrm{~min}$.) as authentic ethyl oxalate and also ethyl oxalate prepared from authentic calcium oxalate (Table II). The extract from the thin-layer plate had the same retention time as authentic ethyl oxalate upon gas chromatography. The results of the gas chromatography on column 2 are shown in Table II.

\begin{tabular}{llll}
\hline & $\begin{array}{l}\text { Ethyl Oxalate } \\
\text { (Authentic) }\end{array}$ & $\begin{array}{l}\text { Derivative from } \\
\text { Calcium Oxalate }\end{array}$ & $\begin{array}{l}\text { Derivative from } \\
\text { Renal Crystals }\end{array}$ \\
\hline Column 1 & $3 \cdot 1$ & $3 \cdot 1$ & $3 \cdot 1$ \\
Column 2 & $4 \cdot 4$ & $4 \cdot 4$ & $4 \cdot 4$ \\
\hline
\end{tabular}

Table II Gas-liquid chromatography retention times (min)

\section{Discussion}

On morphological characteristics the crystals appeared similar to calcium oxalate as seen in oxalosis (Peterson and Kuhn, 1965), ethylene glycol poisoning (Smith, 1951), and in the kidneys of sheep affected by excess oxalate ingestion either from feed containing oxalis pes caprae (Watts, 1959) or acute ammonium oxalate poisoning (James et al, 1971). The large amount of crystal deposited in the kidney probably accounts for the terminal renal failure in a previously well functioning homotransplant. However, scattered foci of lymphocytes seen were consistent with early graft rejection. The unusual finding of small crystals within neurons and midbrain blood vessels most probably explains the terminal neurological findings.

The above series of investigations proves beyond doubt that the crystals deposited in the brain and kidney of a patient who had received 25 and $50 \%$ xylitol infusions intravenously were calcium oxalate. The biochemical reasons and metabolic pathways for the formation of calcium oxalate in these circumstances have been discussed elsewhere by Thomas et al (1972a and b). This report is made because it demonstrates a multidisciplinary approach to one of the aspects of an urgent clinical problem suspected to be related to the intravenous administra- 
tion of xylitol-containing solutions recently introduced into clinical use in South Australia.

References

Donnay, J. D. H. (1963). Crystal Data (Determinative Tables), 2nd ed., p. 547. American Crystallographic Association.

James, M. P., Seawright, A. A., and Steele, D. P. (1971). Experimental acute ammonium oxalate poisoning of sheep. Aust. vet. J., 47, 9-17.

Johnson, F. B. (1956). A method for demonstrating calcium oxalate in tissue sections. (Abstr.) J. Histochem. Cytochem., 4, 404-405.

Johnson, F. B. (1958). Further observations on the identification of calcium oxalate in tissue sections. (Abstr.) J. Histochem. Cytochem., 6,405.

Luft, J. H. (1961). Improvements in epoxy resin embedding methods. J. biophys. biochem. Cytol., 9, 409-414.

Meadows, R., and Schoemaker, H. (1970). Improved processing techniques for renal biopsies for light microscopy. J. clin. Path., 23, 548-550.
Peterson, B. J., and Kuhn, R. J. (1965). Optical characterization of crystals in tissue: cystine and calcium oxalate monohydrate. Amer. J. clin. Path., 43, 401-408.

Reynolds, E. S. (1963). The use of lead citrate at high pH as an electron opaque stain in electron microscopy. J. Cell Biol., 17, 208-212.

Smith, D. E. (1951). Morphologic lesions due to acute and subacute poisoning with antifreeze (ethylene glycol). Arch. Path., 51, 423-433.

Thomas, D. W., Edwards, J. B., Gilligan, J. E., Lawrence J. R., and Edwards, R. G. (1972). Complications following intravenous administration of solutions containing xylitol. Med. J. Aust., 1, 1238-1246.

Thomas, D. W., Gilligan, J. E., Edwards, J. B., and Edwards, R. G. (1972). Lactic acidosis and osmotic diuresis produced by xylitol infusion. Med. J. Aust., 1, 24, 1246-1248.

Watts, P. S. (1959). Effects of oxalic acid ingestion by sheep. 1. Small doses to chaff fed sheep. J. agric. Sci., 52, 244-249.

Whittaker, V. P., and Wijesundera, S. (1952). The separation of esters of choline by filter-paper chromatography. Biochem. J., 51, 348-351.

\section{The December 1972 Issue}

A comparison of two methods of prognostic typing in breast cancer D. R. TURNER AND C. L. BERRY

Spicular arrangement of amyloid in renal biopsy I. D. ANSELL AND A. M. JOEKES

Congenital stenosis and atresia of the jejunum and ileum D. J. desA

The localization of the Australia antigen in the liver by immunofluorescence T. AKEYAMA, T. KAMADA, T. KGIZUMI, AND H. ABE

Measurement of DNA synthesis in leucocyte microcultures J. H. ROBBINS
Latex agglutination in the diagnosis of meningococcal meningitis W. P. J. SEVERIN

Hydrolysis of casein: a differential aid for the indentification of Serratia marcescens WILlIAM A. SALISBURY AND JOSEPH J. LIKOS

Characteristics of some co-trimoxazole-resistant Enterobacteriaceae from infected patients J. BARKER, D. HEALING, AND J. G. P. HUTCHISON

Laboratory assessment of the antimycotic drug clotrimazole R. J. HOLT AND R. L. NEWMAN

\section{Technical methods}

A simple, inexpensive semi-continuous or continuous culture apparatus WILLIAM E. ZERBY, S. GRANT MULHOLLAND, AND SAMUEL J. DE COURCY, JR

An adjustable, semi-automatic dispenser for use with dry absorbents in protein-binding techniques K. H. OUTCH, P. M. DENNIS, AND J. CULROSS

Letter to the Editor

Book Reviews

Index to Volume 25

List of Contents, Volume 25

Copies are still available and may be obtained from the PUBLISHING MANAGER, BRITISH MEDICAL ASSOCIATION, TAVISTOCK SQUARE, WC1H 9JR, price $£ 1.05$ 